\title{
REVIEW
}

\section{The hypothalamic-pituitary-gonadal axis: immune function and autoimmunity}

\author{
F Tanriverdi, L F G Silveira, G S MacColl and P M G Bouloux \\ Department of Medicine, Neuroendocrine Unit, Royal Free and University College Medical School, Rowland Hill Street, London NW3 2PF, UK \\ (Requests for offprints should be addressed to F Tanriverdi; Email: fatihtan@erciyes.edu.tr)
}

\begin{abstract}
GnRH and sex steroids play an important role in immune system modulation and development. GnRH and the GnRH receptor are produced locally by immune cells, suggesting an autocrine role for GnRH. Experimental studies show a stimulatory action of exogenous GnRH on the immune response. The immune actions of $\mathrm{GnRH}$ in vivo are, however, less well established. Oestrogen and androgen receptors are expressed in primary lymphoid organs and peripheral immune cells. Experimental data have established that oestrogens enhance the humoral immune response and may have an activating role in autoimmune disorders. Testosterone enhances suppressor $\mathrm{T}$ cell activity. Although there are some clinical studies consistent with these findings, the impact of sex steroids in
\end{abstract}

autoimmune disease pathogenesis and the risk or benefits of their usage in normal and autoimmune-disordered patients remain to be elucidated. There are neither experimental nor clinical data evaluating functional GnRH-sex steroid interactions within the human immune system, and there is a paucity of data relating to $\mathrm{GnRH}$ analogues, hormone replacement therapy and oral contraceptive and androgen action in autoimmune diseases. However, a growing body of experimental evidence suggests that an extra-pituitary GnRH immune mechanism plays a role in the programming of the immune system. The implications of these findings in understanding immune function are discussed.

Journal of Endocrinology (2003) 176, 293-304

\section{Introduction}

Although interactions between the nervous system, the immune system and the hypothalamic-pituitary-adrenal axis have been extensively investigated, there is recent evidence suggesting that the hypothalamic-pituitarygonadal (HPG) axis may also modulate immune function.

Earlier observations established that compared with males, females display a strikingly increased incidence of autoimmune diseases, and despite intensive investigations, the mechanism of this sexual dimorphism remains elusive. There are other examples of sexual dimorphism in immune function, however. Thus, women have higher plasma immunoglobulin $\mathrm{M}$ levels, a difference most accentuated post-pubertally (Butterworth et al. 1967, Lichtman et al. 1967). Animal models also confirm the sexual dimorphism of both antibody- and cell-mediated immune responses, with females demonstrating greater responsiveness (Eidinger \& Garrett 1972, Weinstein et al. 1984).

Gonadotrophin-releasing hormone $(\mathrm{GnRH})$ and sex steroids are strongly implicated in the development and modulation of the immune system (Schuurs \& Verheul 1990, Mann et al. 1994). Both GnRH and the GnRH receptor (GnRH-R) are expressed in immune subsets (Marchetti et al. 1989a, Chen et al. 1999, Silveira et al. 2002), but hitherto, the physiological role of this extrapituitary immunological axis has been poorly investigated. Sex steroids have binding sites in primary lymphoid organs and peripheral immune cells (Kawashima et al. 1992, Suenaga et al. 1998), implicating both GnRH and sex steroids in immune system modulation, acting through a local autocrine way and/or through HPG axis activation.

The interrelationship between GnRH and/or sex steroids and the immune system should be explored for several reasons. First, there are an increasing number of women using sex steroids, hormone replacement therapy (HRT) or oral contraceptives worldwide. Secondly, in recent years $\mathrm{GnRH}$ agonists have become widely used in a variety of disorders such as precocious puberty, endometriosis and prostatic carcinoma. Thirdly, the underlying mechanisms of sexual dimorphism in autoimmune conditions have not been established. Finally, the potential immune modulatory and programming actions of 
currently used drugs (especially $\mathrm{GnRH}$ analogues) could be investigated in severe immune deficiency conditions such as HIV infection, bone marrow transplantation (BMT) and after high-dose chemotherapy in cancer patients when immune reconstitution has crucial importance.

This review focuses on the impact of $\mathrm{GnRH}$ and sex steroids in both immune system modulation and autoimmune disorders.

\section{GnRH and the immune system: experimental studies}

\section{Expression and binding sites}

Specific GnRH-binding sites have been reported in cultured porcine lymphocytes (Standaert et al. 1992), rat thymus (Marchetti et al. 1989a, Morale et al. 1991) and in rat spleen (Batticane et al. 1991). Maier and colleagues first reported the expression of thymic GnRH (identical to hypothalamic $\mathrm{GnRH}$ ) in neonatal rat pups using PCRbased technology (Maier et al. 1992, Maier \& Blalock 1994). Expression of GnRH mRNA was subsequently demonstrated in porcine immune cells (thymus, spleen, peripheral lymphocytes) (Weesner et al. 1997), in murine thymus and spleen (Jacobson et al. 1998) and in a rat immature T cell line (Wilson et al. 1995b).

Observations in human cells yielded similar results. Immunoreactive and bioactive $\mathrm{GnRH}$ has been demonstrated in human peripheral $\mathrm{T}$ cells $(\mathrm{CD} 4+, \mathrm{CD} 8+)$ and in a leukaemic cell line (Jurkat) similar to $\mathrm{T}$ lymphocytes (Azad et al. 1993, 1997); GnRH and GnRH-R mRNA transcripts are also demonstrable in human peripheral lymphocytes and in B lymphocytes (Chen et al. 1999, Silveira et al. 2002). GnRH-R expression is up-regulated by native $\mathrm{GnRH}$, suggesting an autocrine function for this hormone in immune cells (Chen et al. 1999). Our laboratory has also confirmed not only the expression and presence of GnRH type-I but also of GnRH type-II transcript and peptides in human peripheral mononuclear cells and in B lymphocytes using RT-PCR, as well as by immunocytochemistry. Moreover, in an ongoing study, we have demonstrated the regulation of $\mathrm{B}$ lymphocyte proliferation by local and exogenous GnRH-I (F Tanriverdi \& PMG Bouloux, unpublished observations). Although the clinical significance of GnRH mRNA expression and the presence of GnRH in immune cells is not clear yet, the activity of GnRH within the immune system appears distinct from its role within the pituitary. It has been established that GnRH concentrations are low in the portal system (Eskay et al. $1975)$ and further diluted (10-35 pg/ml) and metabolised in the general circulation; furthermore, no significant change in plasma GnRH concentration has been detected during the menstrual cycle (Aksel 1979). Hypothalamic GnRH is therefore unlikely to represent the endogenous ligand for immune cells. Rather, recent findings support a probable physiological immune action of extra-pituitary GnRH (Chen et al. 1999, Jacobson et al. 1999a).

\section{$\mathrm{GnRH}$ and immune system development}

The direct involvement of GnRH in thymus maturation and development of cell-mediated and humoral immune responses in rats was first demonstrated by Morale et al. (1991). Treatment of neonatal female rats with a GnRH antagonist blocked the thymocyte proliferative response, decreased thymus weight, reduced CD4+ T lymphocyte subsets and decreased the antibody response to antigenic stimulus in adult age (3-month-old) animals. These findings clearly showed the important physiological role of GnRH in immune system development and the longterm effects of $\mathrm{GnRH}$ blockage on immune function (Morale et al. 1991). Recently, the potential role of $\mathrm{GnRH}$ in prenatal and postnatal programming of immune cells has been confirmed by Zakharova et al. (2000), within the rat embryo thymus. Intra-uterine injections of a $\mathrm{GnRH}$ antagonist and antibodies to 20-day-old rat fetuses were shown to suppress concanavalin-A-activated thymocyte proliferation, suggesting a prenatal action of $\mathrm{GnRH}$ in modulating $\mathrm{T}$ cell immune development and thymocyte proliferation.

$\mathrm{GnRH}$ antagonist injection into primates (Callithrix jacchus) within the first days after birth decreased the number of $\mathrm{B}$ and $\mathrm{T}$ lymphocytes in the thymus and spleen (Mann et al. 1998) and the number of circulating lymphocytes observed up to 5 years of age (Gould et al. 1998). By contrast, a single i.m. injection of a long-acting GnRH agonist in prepubertal mice produced a general suppression of leukocyte maturation in primary lymphoid organs ( $R$ ao et al. 1993). In a further study by the same authors, $50 \mu \mathrm{g}$ of a GnRH analogue (Lupron depot) were administered to different strains of mice; a stimulatory effect of the $\mathrm{GnRH}$ agonist on stem cell maturation in lymphoid tissue was demonstrated in some strains (Rao et al. 1995). Taken together, these data suggest that $\mathrm{GnRH}$ has a modulatory effect in humoral and cellular immune system development, an effect mediated via a classical GnRH-R type-I.

\section{Immune effects of $\mathrm{GnRH}$}

Studies in humans and rodents demonstrate that GnRH possesses potent stimulatory immune actions. In both the ageing male and female rat, the parallel decreases in both thymic GnRH-binding sites and thymus weight are reversed by chronic (45 day) potent $\mathrm{GnRH}$ analogue (GnRH-N-ethylamide) treatment (Marchetti et al. 1989b). Interleukin-2 (IL-2) is an important cytokine in proliferation and/or activation of $\mathrm{T}$ and $\mathrm{B}$ cells; its receptor (IL2R) expression was stimulated in rat thymocyte and splenocyte cultures incubated with native $\mathrm{GnRH}$ and its analogue in the absence of any other mitogenic stimulus, 
Table 1 Summary of experimental data showing the effects of $\mathrm{GnRH}$ on the immune system

Expression of GnRH and GnRH-R

Immune system development

Immune effects

Impact on autoimmunity

Sexually dimorphic immune response
Both expressed in primary lymphoid organs and peripheral immune cells including human lymphocytes

Involved in immune system development No data in humans

Potent immune-stimulating action Increases the levels of IL2R, IFN- $\gamma$, T helper cells

Potential to exacerbate autoimmune disease Effect independent from gonadal steroids

Different expression of GnRH-R and/or G proteins in males and females? an effect reversed by a GnRH antagonist (Batticane et al. 1991). In another study, native GnRH significantly enhanced in vitro interferon- $\gamma$ (IFN- $\gamma$ ) production by human peripheral mononuclear cells (Grasso et al. 1998). In an animal model of immunodeficiency, total IgG levels and CD4+ lymphocytes increased after 7 weeks of native GnRH administration (Jacobson et al. 1999b), invoking a direct stimulatory effect of $\mathrm{GnRH}$ on immune function.

One corollary of this is that GnRH may constitute one of the factors in thymic immune reconstitution. Thymopoiesis is an essential process for establishing the peripheral $T$ cell pool in early life. The capacity of the thymus to export new $\mathrm{T}$ cells to the periphery begins to decrease at age 1 year (Steinmann et al. 1985), and although there is an age-dependent decline in thymic function (thymic ageing), $\mathrm{T}$ lymphopoiesis remains active in the human throughout life (Flores et al. 1999, Jamieson et al. 1999, Poulin et al. 1999). Thymic function gains additional importance in immune deficiency conditions such as HIV infection, BMT and the leukopenic period after high-dose chemotherapy, when immune reconstitution is required. Sempowski et al. (2000) identified a group of cytokines such as IL-2, IL-10 and IL-14 whose expression levels decreased during thymic ageing. GnRH administration has been shown to increase rat thymic expression of IL2R in rat thymus and circulating CD4+ levels in an animal model of immunodeficiency (Batticane et al. 1991, Jacobson et al. 1999b). Even though data in humans are sparse, GnRH and GnRH analogues increase IL2R expression in lymphocytes after $24 \mathrm{~h}$ exposure, in a dose-dependent manner (Chen et al. 1999). While the clinical significance of this short-term effect on lymphocyte function is not clear yet, these experimental data underline the potential implication of $\mathrm{GnRH}$ and $\mathrm{GnRH}$ analogues in immune reconstitution. Could GnRH analogues be used as adjunctive therapy in such indications as HIV or BMT?

\section{Impact of $\mathrm{GnRH}$ on autoimmunity and gender-specific immune response}

The pathogenesis of autoimmune diseases is complex, and hormonal, genetic, psychological and environmental factors contribute to the development and activation of these conditions. Jacobson et al. (1994) suggested that GnRH might play a role in the exacerbation of autoimmune disorders. They assessed disease severity in intact and castrated, male and female, systemic lupus erythematosus (SLE)-prone $(\mathrm{SWR} \times \mathrm{NZB}) \mathrm{F} 1$ hybrid mice during treatment with a GnRH agonist (native decapeptide) and antagonist (Nal-Glu) (100 $\mu$ s.c. injections with GnRH agonist or antagonist, six times weekly). After 12 weeks of GnRH antagonist administration, total serum levels of IgG and anti-DNA antibodies were reduced, severity of renal disease decreased and survival improved significantly. Interestingly these effects were noted in intact and castrated mice in both sexes, suggesting that the protection conferred by $\mathrm{GnRH}$ antagonists was independent of gonadal steroids (Jacobson et al. 1994). On the other hand, they also demonstrated sexually dimorphic actions (disease severity was higher in females) of $\mathrm{GnRH}$ agonists even in gonadectomised mice. Based on their data, it was hypothesised that differences in responsiveness to $\mathrm{GnRH}$ might be due to gender differences in expression of GnRH-R or due to gender differences in expression of $G$ proteins (Jacobson et al. 1999a, Jacobson 2000, Walker \& Jacobson 2000). These explanations might partially explain gender differences in immune function. However, could these observations explain the different expression of $\mathrm{GnRH}$ and/or $G$ proteins between sexes? The relationship between $\mathrm{GnRH}$ and sex steroids in immunomodulation will be addressed later.

In summary, GnRH seems to be directly involved in cellular and humoral immune development. However, the role of $\mathrm{GnRH}$ in immune modulation and autoimmune responses during adulthood is still under investigation; current known actions of GnRH in the immune system are summarised in Table 1.

\section{Sex steroids and the immune system: experimental studies}

Several experimental studies suggest that sex steroids influence immune cell development in primary lymphoid tissues (bone marrow and thymus) and, in addition, have 
immunomodulatory effects on both peripheral $\mathrm{T}$ cell and B cell subsets in adult life.

\section{Receptor expression in primary lymphoid organs}

Early studies showed that in rats and mice, castration induced thymic enlargement, an effect reversed by androgen replacement, suggesting the presence of specific androgen-binding sites in thymic cells (Fitzpatrick et al. 1985, Olsen et al. 1991). Androgen receptors (ARs) have been demonstrated in thymocytes by Western blot and flow cytometry in mice (Viselli et al. 1995) and radioligand binding assays in humans (Kovacs \& Olsen 1987). Several studies have also demonstrated oestrogen receptor (ER) expression in thymocytes and thymic epithelial cells in both mice and humans (Nilsson et al. 1986, Kawashima et al. 1992). Oestrogen interacts with two distinct nuclear receptors, ER- $\alpha$ and ER- $\beta$. The human (Mosselman et al. 1996) and mouse (Tremblay et al. 1997) ER- $\beta$ homologues have recently been cloned. In the male ER- $\alpha$ knockout mice, the role of ER- $\alpha$ in thymic development and oestrogen-induced thymocyte phenotypic shift has been clearly demonstrated (Staples et al. 1999), and the requirement for ER- $\alpha$ in thymic development in both sexes during the postnatal period established (Yellayi et al. 2000). A recent study in ER- $\alpha$ - and/or ER- $\beta$-disrupted mice established that ER subtypes have different roles in females and males. ER- $\alpha$ was shown to be essential for thymic and splenic development in males, whereas expression of ER- $\beta$ was required for oestrogen-mediated thymic cortex atrophy and thymocyte phenotypic shift in females (Erlandsson et al. 2001).

In mammals, B cells are produced in the bone marrow. Studies in mice have confirmed effects of androgens on developing B cells mediated through ARs, expressed in bone marrow stromal cells (Bellido et al. 1995, Olsen et al. 2001). These cells have also been shown to contain functional ER (Bellido et al. 1993, Smithson et al. 1995). Recent studies have demonstrated that B cell lymphopoiesis is normal in female ER- $\alpha$-disrupted mice (Smithson et al. 1998), suggesting that ER- $\beta$ might be responsible for regulation of $\mathrm{B}$ cell formation in bone marrow (Kincade et al. 2000).

\section{Receptor expression in peripheral $B$ and $T$ cells}

As in primary lymphoid organs, ER transcripts were identified in mature peripheral $\mathrm{B}$ and $\mathrm{T}$ lymphocytes both in healthy subjects and in patients with SLE (Suenaga $e t$ al. 1998). By contrast, ARs have not been documented in mature peripheral T and B lymphocytes (Olsen \& Kovacs 2001), rendering genomic actions of androgens unlikely. Nevertheless it was demonstrated that testosterone induces calcium influx, presumably via non-genomic surface receptors, in activated murine splenic mature $\mathrm{T}$ cells
(Benten et al. 1997, 1999); the functional repercussions of this have not been established.

In summary, oestrogen and ARs are expressed in primary lymphoid organs and ERs are expressed in mature peripheral $\mathrm{B}$ and $\mathrm{T}$ cells, supporting the action of sex steroids in immune system development and modulation.

\section{Effects of androgens on cellular and humoral immunity}

Several studies in both animals and humans have been performed in an attempt to understand the influence of sex steroids on the immune system. Androgens exert considerable effects on the size and composition of the thymus. Removal of androgens by castration resulted in thymic enlargement even in old rats and androgen replacement reversed this effect (Greenstein et al. 1986). In one study, testosterone replacement in castrated male mice caused thymic regression, with a shift towards expression of mature thymocytes and predominance of the suppressor/ cytotoxic CD4-CD8+ phenotype over the helper CD4+CD8 - phenotype (Olsen et al. 1991). Mechanisms of androgen-induced thymus involution are incompletely understood, but decreased cell proliferation, changes in cell trafficking and increased apoptosis are some of the possible mechanisms involved. The role of apoptosis was suggested by one study from Olsen et al. (1998), in which a single dose of testosterone markedly decreased thymic size within hours in castrated mice; increased DNA fragmentation was shown, suggesting thymocyte apoptosis. Recently, it has been shown that testosterone specifically targets double positive $(\mathrm{CD} 8+\mathrm{CD} 4+)$ thymocytes for apoptosis via upgrading tumour necrosis factor- $\alpha$ production (Guevara Patino et al. 2000). On the other hand, documentation of classical AR expression in peripheral $\mathrm{T}$ cells has not been reported but the net effect of androgen action (direct or indirect) seems to be an enhanced suppressor effect (Olsen \& Kovacs 1996).

The number of pre-B cells in bone marrow and mature peripheral B cells increases in male mice after castration (Wilson et al. 1995a). It has been reported that treatment of mice with dihydrotestosterone (a non-aromatisable androgen) suppressed the expansion of lineage precursors (IL-7 responsive precursors) when added to short-term co-cultures of lymphocytes and stromal cells (Medina \& Kincade 1994, Smithson et al. 1998).

There are conflicting data concerning the effects of castration and androgens on peripheral B cells. CD5+ cell subsets have been implicated as an important source of autoantibodies. An early study showed that this B cell subset did not expand in spleens of castrated male mice, whereas oestrogen treatment in female mice augmented the CD5+ cell subset activity (Ansar et al. 1989), suggesting the greater importance of oestrogen (rather than absence of androgen) in activation of CD $5+$ cell subsets. In a recent study, castration in male mice was shown to 
selectively increase splenic cellularity and the number of peripheral blood lymphocytes due to newly emigrated immature $\mathrm{B}$ cells. It was concluded that the numbers of B cells in male mice were controlled by physiological levels of androgen (Ellis et al. 2001).

\section{Pregnancy and the immune system}

Pregnancy is a good physiological model for evaluating the effects of oestrogen and progesterone on the thymus and $\mathrm{T}$ cells. Thymic involution in mice is accelerated during pregnancy and the size of the thymus gradually returns to normal in the first month postpartum (Phuc et al. 1981). Activation of the humoral immune response, shift to the $\mathrm{T}$ helper 2 (TH2) pathway and a decreased cellular immune response have been determined during pregnancy. The most striking clinical example of this immune profile change is SLE, in which a humoral immune response is an important pathogenetic factor, exacerbated by pregnancy. By contrast, rheumatoid arthritis and multiple sclerosis (disorders related to cellular immune response TH1 pathways) improve during pregnancy (Lahita et al. 1986, Holmdahl 1989). Although the exact mechanism is unclear, high levels of oestrogen, progesterone and other possible hormones such as prolactin may be responsible for these immune profile changes (Walker et al. 1998, Whitacre 2001). Even though there is a reduction in circulating levels of immunoreactive GnRH during pregnancy (Petraglia et al. 1996), recently it has been reported that human placenta expresses GnRH and GnRH-R (Wolfahrt et al. 1998). In addition to being a potential autocrine/paracrine regulator of human chorionic gonadotrophin biosynthesis (Barnea \& Kaplan 1989, Currie et al. 1993), placental GnRH may have a contribution in immune system changes during pregnancy via a paracrine route or indirectly through regulation of placental hormones, and given the aforementioned, this may be a fertile area of future investigation.

\section{Effects of oestrogens on cellular and humoral immunity}

Oestrogen treatment has been shown to cause significant thymic atrophy and to decrease the number of thymocytes in mice (Okuyama et al. 1992). In a study with ovariectomised female rats, ovariectomy increased thymic size and had a profound effect on the thymocyte profile, leading to an increase in the CD4+CD8+ immature cells, with a decrease in the relative proportion of the mature cells, which was opposed by treatment with physiological doses of oestradiol-17 $\beta$ (Leposavic et al. 2001). Oestrogen also stimulates CD4+CD8 - cells and can activate an extra-thymic pathway of autoreactive $\mathrm{T}$ cell differentiation in the liver (Screpanti et al. 1989, Okuyama et al. 1992, Muller et al. 1995).

Several studies have established that oestrogen is a potent inhibitor of stromal cell-dependent B cell lym- phopoiesis in vitro. In bone marrow, all the precursors beyond the early pro-B cell stage are affected by oestrogen (Medina et al. 1993, Medina \& Kincade 1994, Smithson et al. 1995). In a recent study, the same authors observed a dramatic reduction in $\mathrm{B}$ cell lineage differentiation and expansion when oestrogen was added to stromal-free cultures, suggesting a direct effect of oestrogen on early pro-B cells (Kincade et al. 2000).

Oestrogen also affects peripheral B cells and humoral immunity. Oestrogen treatment in normal male or female mice increased the number of antibody-producing cells and the levels of circulating autoantibodies (against double-stranded (ds) DNA) without any increase in B cell count (Verthelyi \& Ahmed 1994). In another study, using human peripheral blood mononuclear cells, oestrogen treatment was showed to enhance immunoglobulin production, partially by increasing IL-10 production (Kanda \& Tamaki 1999).

In summary, androgens and oestrogen are potent immune modulators. Sex steroids act as negative regulators in both the thymus and bone marrow, but androgens and oestrogen tend to affect different subsets of immune cells. In general, androgens seem to inhibit immune activity, while oestrogen seems to have a more powerful effect on immune cells and to stimulate immune activity.

Impact of sex steroids on autoimmunity and gender-specific immune response

Autoimmune disorders are typically more common in women and, therefore, a role for sex steroids in the sexually dimorphic response of the immune system might be expected. (NZB $\times \mathrm{NZW})$ F1 mice $(\mathrm{B} / \mathrm{W}$ mice), an animal model of SLE, have been widely used to investigate the impact of sex steroids in autoimmunity.

In early studies, premature death and a disease course indistinguishable from untreated females were reported in orchiectomised $\mathrm{B} / \mathrm{W}$ mice. In females, ovariectomy did not alter the disease course, but further administration of dihydrotestosterone lowered anti-DNA antibody levels and improved the prognosis (Roubinian et al. 1977a), suggesting a protective role for androgens rather than a deleterious effect of oestrogen (Roubinian et al. 1978, Siiteri et al. 1980). On the other hand, thymectomy of intact male $\mathrm{B} / \mathrm{W}$ mice decreased the protective effects of endogenous androgens (Roubinian et al. 1977b).

In contrast to androgen administration, oestrogen treatment of castrated females enhanced disease progression and death (Roubinian et al. 1978, Siiteri et al. 1980). It was reported that normal female mice (C57BL/6) have higher autoantibody levels than males. In addition, chronic administration of oestradiol increased the autoantibody (IgG anti-cardiolipin and anti-dsDNA) production in both normal female and male mice (Ahmed \& Verthelyi 1993, Verthelyi \& Ahmed 1994, Verthelyi \& Ansar 1997). 
Table 2 Summary of experimental data showing the effects of sex steroids on the immune system

Expression of receptors

Thymus and bone marrow effects

Peripheral $\mathrm{T}$ and $\mathrm{B}$ cells

Impact on autoimmunity

Sexually dimorphic immune response
$E R$ and $A R$ expressed in all immune subsets, except $A R$ in mature $B$ and $T$ cells

Testosterone: thymic atrophy, thymocyte apoptosis and B cell precursor depletion in bone marrow Oestrogen: same as testosterone, but on different immune subsets

Testosterone: enhances suppressor T cells and diminishes B cell number

Oestrogen: enhances helper T cells and increases autoantibody production

Androgens: seem to have suppressor activity Oestrogens: seem to have stimulating activity

Impact is more during development of immune response; mechanism is unclear
The relationship between sex steroids and autoimmunity was demonstrated not only in the SLE mouse model, but also in insulin-dependent diabetes mellitus and an animal model of autoimmune thyroiditis (Ahmed \& Talal 1990, Fox 1992). In all these studies, oestradiol seemed to accelerate the progression of humoral immune responsedependent autoimmune diseases via enhancing the TH2 pathway, while androgen had a protective effect. Another hormonally modulated autoimmune disease model which has been extensively studied is experimental allergic encephalitis (EAE). EAE is a cellular immune response (TH1 pathway)-dependent autoimmune disease that has proved a useful model of multiple sclerosis. Several studies in EAE rat and mouse models have demonstrated the potent suppressive effects of oestrogens on disease activity (Jansson et al. 1994, Kim et al. 1999, Hoffman et al. 2001).

It is proposed that specific responses of different immune subsets to androgens and oestrogens could be one of the contributing factors in sexual dimorphism in the immune system (Olsen et al. 1998). Previous studies have shown that the dimorphic immune response is fully established after puberty (Blazkovec \& Orsini 1976, Aaron et al. 1985). However, in a recent study, it was clearly demonstrated that sexual dimorphism in the composition of thymocyte subsets persisted after the gonadectomy of adult rats, suggesting that gonadal steroids are more important for the development than for the maintenance of the gender difference in immune responsiveness (Leposavic et al. 1996).

The main relationships between sex steroids and immune system are summarised in Table 2 . Although the full nature and underlying mechanisms are still poorly understood, future molecular studies are likely to elucidate the relationships between sex steroids and immune cells.

\section{Sex steroids and GnRH interaction}

Is there an interaction demonstrable between sex steroids and GnRH within the immune system? Oestrogen regu- lates the number of GnRH-Rs in the pituitary, modulating the responsiveness of gonadotrophs to $\mathrm{GnRH}$ (McArdle et al. 1992). One suggested mechanism for oestrogen regulation of GnRH-R includes modulation of GnRH-R mRNA levels (Bauer-Dantoin et al. 1993, Funabashi et al. 1994, Quinones-Jenab et al. 1996). Direct regulation of human GnRH-R expression by progesterone at pituitary and placental levels was recently shown, and the presence of a putative progesterone response element in the $5^{\prime}$-flanking region of the human GnRH-R gene has been established (Cheng et al. 2001).

In an elegant study, Azad et al. (1998) demonstrated that gonadal steroids could also modulate the production of GnRH by immune cells. In this study, thymic GnRH concentrations were significantly increased in castrated rats, but testosterone replacement inhibited this increment. Other studies showed that the increase in oestrogen concentrations during the oestrous cycle in mice and rats was associated with increased expression of $\mathrm{GnRH}$ and GnRH-R mRNA in both spleen and thymus (Jacobson et al. 1998, Marchetti et al. 2000, Morale et al. 2001). Interactions between $\mathrm{GnRH}$, sex steroids and immune cells are shown in Fig. 1.

\section{The HPG axis and the immune system: clinical studies}

\section{GnRH agonist treatment}

GnRH analogues are used in the treatment of several conditions, such as precocious puberty (Neely et al. 1992), endometriosis (Waller \& Shaw 1993), leiomyomas (Coddington et al. 1992), prostatic carcinoma (Huben 1992) and other hormone-dependent cancers. Studies in women receiving $\mathrm{GnRH}$ analogue treatment for endometriosis showed an increase in natural killer (NK) cell numbers and up-regulation of $\mathrm{T}$ cell mitogenic activity after 1 year of follow-up (Garzetti et al. 1996, Hsu et al. 1997). No new case of autoimmune disorder was reported among the women participating in these studies. Ho et al. 
B cell activity

$\uparrow$ proliferation (3)

$\uparrow \operatorname{GnRH-R}\left(1^{* *}, 3\right)$

$\uparrow \operatorname{IL} 2 \mathrm{R}(3)$

$\uparrow \operatorname{IgG}(1,3)$

$\uparrow$ AutoAb $(1,3)$

$\downarrow$ AutoAb (2)

$\uparrow \mathrm{CD} 5(+)$ cells $(1)$

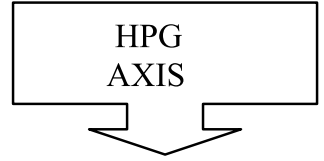

SEX STEROIDS
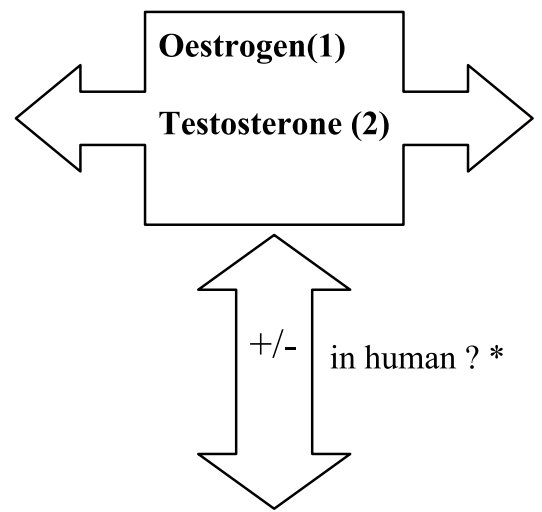

\section{$\underline{T}$ cell activity}

$\uparrow$ proliferation(3)

$\uparrow$ GnRH-R $\left(1^{* *}, 3\right)$

$\uparrow \operatorname{IL} 2 \mathrm{R}(3)$

$\uparrow \mathrm{CD} 4(+), \mathrm{CD} 8(-)$ cells $(1,3)$

$\uparrow \mathrm{CD} 4(-), \mathrm{CD} 8(+)$ cells(2)

$\uparrow \mathrm{CD} 4(+) / \mathrm{CD} 8(-)$ ratio (1)

个 IL-10 (1)

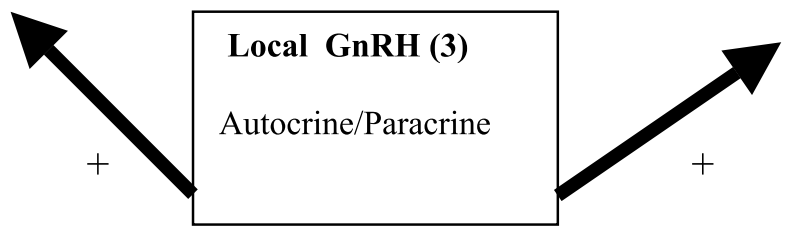

Figure 1 Diagrammatic representation of experimental data for sex steroid, GnRH and immune system interactions. The HPG axis affects B and T cell activity via sex steroids in both stimulatory or inhibitory ways. Local GnRH produced by immune cells or tissues has an immune stimulatory action in autocrine/paracrine ways. There are possible interactions between sex steroids and local GnRH at the immune system level. ${ }^{*}$ In the human, sex steroid-GnRH interaction at the immune system level is unknown; ${ }^{* *}$ Oestrogens increase GnRH mRNA in immune cells in mice. (1) Oestrogen effect; (2) testosterone effect; (3) GnRH effect.

(1995) analysed the immune profile of patients receiving GnRH analogues during in vitro fertilisation programmes and, in contrast to data obtained in experimental studies, no changes were observed in peripheral B cells, NK cells, CD4+ and CD8+ T cells, and serum IL-2 and IL2R levels. On the other hand, exacerbation of SLE nephritis and thrombocytopenia after GnRH analogue administration has been reported in two different case reports (Miyagawa et al. 1994, Metcalfe \& Boulton-Jones 1997). In a contradictory study, Catania et al. (1989) reported improvement in the disease course of six SLE patients due to down-regulation of gonadotrophin secretion after $\mathrm{GnRH}$ analogue administration. More clinical studies are warranted to establish the role of $\mathrm{GnRH}$ agonists in immune function.

\section{Hypogonadism and autoimmunity}

In primary hypogonadism, hypothalamic-pituitary production of GnRH and gonadotrophins is increased, but there are no data about the effects of this condition on the GnRH and GnRH-R expressed in immune cells. Nevertheless, in either primary or secondary hypogonadism some relevant immune changes might be expected due to low sex steroid levels.

Increased incidence of autoimmune disorders in hypogonadal states have been reported in several studies. Examples of this include increased occurrence of autoimmune thyroid diseases in premature ovarian failure (Belvisi et al. 1993) and SLE in Klinefelter's syndrome (Stern et al. 1977, French \& Hughes 1983). The latter is characterised by low androgen levels, often associated with elevated oestrogen levels. Increased CD4+ T cell count, CD4+/ CD8+ ratio, immunoglobulin levels and IL-2 levels have been reported in untreated Klinefelter's syndrome patients with no autoimmune disorder, confirming experimental studies. Androgen replacement significantly reversed all these changes (Kocar et al. 2000). In some Klinefelter's syndrome patients with autoimmune disorders, androgen replacement decreases the activity of the disease and 
depresses the humoral immune response via lowering CD4+/CD8+ ratios (Bizzarro et al. 1987, Olsen \& Kovacs 1995).

Similar immune profile changes were demonstrated in male patients with idiopathic hypogonadotrophic hypogonadism $(\mathrm{IHH})$ before and after gonadotrophin treatment; testosterone normalisation was associated with a decrease in $\mathrm{CD} 4+/ \mathrm{CD} 8+$ ratio and immunoglobulin levels (Yesilova et al. 2000). However, in a previous study, although CD4+ cells were significantly higher in untreated IHH patients compared with normal adults and treated patients, the CD4+/CD8+ ratio did not change after normalisation of testosterone (Kiess et al. 1991).

\section{The impact of HRT and oral contraceptives on immune function: risk or benefit?}

The associations between oestrogen treatment and the risk of development or exacerbation of autoimmune disorders have been evaluated in several studies. Consistent with experimental studies, increased levels of oestrogens and active oestrogen metabolites have been shown in SLE patients (Lahita et al. 1982, Folomeev et al. 1992). Moreover, it is known that exacerbations of SLE commonly occur during pregnancy, a high-oestrogen state, due to increased TH2 cytokines (IL-4, IL-10) and correspondingly enhanced humoral immunity (Ostensen 1999). In some clinical studies, it was suggested that long-term use of postmenopausal oestrogen therapy might be associated with increased SLE risk (Sanchez-Guerrero et al. 1995). Sanchez-Guerrero et al. (1995) investigated nearly 70000 postmenopausal women in a prospective study (Nurses' Health Study), using health questionnaires, and found an approximately 2-fold increased age-adjusted relative risk for SLE in women receiving HRT (Meier et al. 1998). However, this study was not a randomised trial designed to test the association between HRT and SLE, and different HRT schedules were not assessed (Buyon et al. 1995). In a recent study, B cell subsets were evaluated in postmenopausal women. CD5 - cells were decreased in late postmenopausal women and increased after 6 months of HRT; however, HRT did not affect autoantibodyproducing cell CD5+ count, and moreover, HRT did not appear to increase the risk of autoimmune disease (Kamada et al. 2001). In addition, it was suggested that HRT might protect women from an aberration of the immune system via improving the cellular and humoral immune response balance (Deguchi et al. 2001).

SLE and other autoimmune pathologies seem to be associated with impaired NK cell activity and B cell hyperactivity. In an elegant study, effects of sex steroids on immune cells' profile levels were assessed in 30 male-tofemale and 30 female-to-male transsexuals. Oestrogen plus anti-androgen administration to males significantly decreased NK cell numbers and a slight increase was found in the number of $\mathrm{B}$ cells. In addition, a shift towards the
TH1 phenotype was found in females receiving testosterone, while the opposite was seen in males after oestrogen plus anti-androgen treatment (Giltay et al. 2000).

Effects of HRT and oestradiol treatment on autoimmune disease progression are uncertain. Although the number of patients analysed was small, retrospective (Arden et al. 1994) and prospective studies (Kreidstein et al. 1997, Mok et al. 1998) have shown that HRT does not increase flare rates and disease severity. Women with SLE have an elevated risk of osteoporosis and coronary artery disease due to ovarian dysfunction and prolonged use of corticosteroids (Petri et al. 1992, Kipen et al. 1998). In theory, these patients might have potential benefit from HRT treatment but there are insufficient data available at the moment to confirm this. The SELENA Trial (the Safety of Estrogens in Lupus Erythematosus - National Assessment) is currently in progress in the USA. This randomised, placebo-controlled, multicentre trial is assessing the use of oral contraceptive and HRT in female patients with SLE and may shed more light on this issue.

\section{Conclusions and future directions}

Although definitive mechanisms have not been elucidated yet, GnRH and sex steroids seem to be important components of immune system modulation and may play a role in the pathogenesis of autoimmune disorders. Effects of these hormones are not only limited to immune modulation. Actions of sex hormones during embryonic development appear to be important for immune system programming and gender differences in immune responsiveness.

GnRH and GnRH-R are produced locally by immune cells, suggesting an autocrine role for GnRH. Most experimental studies have shown that exogenous GnRH stimulates the immune response. However, there are conflicting results in clinical studies regarding the immune effects of currently used GnRH analogues.

ERs and ARs are expressed in primary lymphoid organs and peripheral immune cells, except for mature $\mathrm{B}$ and $\mathrm{T}$ cells in which ARs are not demonstrable. Experimental data have established that oestrogens enhance the humoral immune response and seem to have an activating role in autoimmune disorders, whereas testosterone enhances suppressor $\mathrm{T}$ cell activity. Although there are some clinical studies consistent with these findings, the impact of sex steroids on autoimmune disease pathogenesis, and the risk or benefits of their usage in normal and autoimmune disordered patients, require further investigation.

There are neither experimental nor clinical data evaluating $\mathrm{GnRH}$ and sex steroid interaction at the immune system level in humans, and several questions remain to be answered in this area. For example, does GnRH-R have signalling capacity on human immune cells and can sex steroids modulate GnRH and GnRH-R expression in 
human immune cells as they do in the HPG axis? Does GnRH have a direct effect on immune cells, via stimulation of local GnRH-Rs? Or does it only act indirectly via activating the HPG axis and increasing circulating levels of sex steroids? Answers to these questions are important if the immune-modulating mechanisms of GnRH and sex steroids are to be clarified.

The immune aspects of currently used medications such as $\mathrm{GnRH}$ analogues, oestrogens and androgens need to be further evaluated for risk of autoimmune disorder development and for potential application in new indications in decreased immune response conditions such as HIV infection and after BMT.

\section{References}

Aaron S, Fraser PA, Jackson JM, Larson M \& Glass DN 1985 Sex ratio and sibship size in juvenile rheumatoid arthritis kindreds. Arthritis and Rheumatism 28 753-758.

Ahmed SA \& Talal N 1990 Sex hormones and the immune system Part 2. Animal data. Bailliere's Best Practice and Research. Clinical Rheumatology 4 13-31.

Ahmed SA \& Verthelyi D 1993 Antibodies to cardiolipin in normal C57BL/6J mice: induction by estrogen but not dihydrotestosterone. Journal of Autoimmunity 6 265-279.

Aksel S 1979 Luteinizing hormone-releasing hormone and the human menstrual cycle. American Journal of Obstetrics and Gynecology 135 96-101.

Ansar AS, Dauphinee MJ, Montoya AI \& Talal N 1989 Estrogen induces normal murine CD5+ B cells to produce autoantibodies. Journal of Immunology 142 2647-2653.

Arden NK, Lloyd ME, Spector TD \& Hughes GR 1994 Safety of hormone replacement therapy (HRT) in systemic lupus erythematosus (SLE). Lupus 3 11-13.

Azad N, La Paglia N, Jurgens KA, Kirsteins L, Emanuele NV, Kelley MR, Lawrence AM \& Mohagheghpour N 1993 Immunoactivation enhances the concentration of luteinizing hormone-releasing hormone peptide and its gene expression in human peripheral T-lymphocytes. Endocrinology 133 215-223.

Azad N, La Paglia N, Kirsteins L, Uddin S, Steiner J, Williams DW, Lawrence AM \& Emanuele NV 1997 Jurkat cell proliferative activity is increased by luteinizing hormone-releasing hormone. Journal of Endocrinology 153 241-249.

Azad N, La Paglia N, Agrawal L, Steiner J, Uddin S, Williams DW, Lawrence AM \& Emanuele NV 1998 The role of gonadectomy and testosterone replacement on thymic luteinizing hormonereleasing hormone production. Journal of Endocrinology 158 229-235.

Barnea ER \& Kaplan M 1989 Spontaneous, gonadotropin-releasing hormone-induced, and progesterone-inhibited pulsatile secretion of human chorionic gonadotropin in the first trimester placenta in vitro. Journal of Clinical Endocrinology and Metabolism 69 215-217.

Batticane N, Morale MC, Gallo F, Farinella Z \& Marchetti B 1991 Luteinizing hormone-releasing hormone signaling at the lymphocyte involves stimulation of interleukin-2 receptor expression. Endocrinology 129 277-286.

Bauer-Dantoin AC, Hollenberg AN \& Jameson JL 1993 Dynamic regulation of gonadotropin-releasing hormone receptor mRNA levels in the anterior pituitary gland during the rat estrous cycle. Endocrinology 133 1911-1914.

Bellido T, Girasole G, Passeri G, Yu XP, Mocharla H, Jilka RL, Notides A \& Manolagas SC 1993 Demonstration of estrogen and vitamin $\mathrm{D}$ receptors in bone marrow-derived stromal cells: up-regulation of the estrogen receptor by 1,25-dihydroxyvitamin-D3. Endocrinology 133 553-562.
Bellido T, Jilka RL, Boyce BF, Girasole G, Broxmeyer H, Dalrymple SA, Murray R \& Manolagas SC 1995 Regulation of interleukin-6, osteoclastogenesis, and bone mass by androgens. The role of the androgen receptor. Journal of Clinical Investigation 95 2886-2895.

Belvisi L, Bombelli F, Sironi L \& Doldi N 1993 Organ-specific autoimmunity in patients with premature ovarian failure. Journal of Endocrinological Investigation 16 889-892.

Benten WP, Lieberherr M, Sekeris CE \& Wunderlich F 1997 Testosterone induces $\mathrm{Ca}^{2+}$ influx via non-genomic surface receptors in activated $\mathrm{T}$ cells. FEBS Letters 407 211-214.

Benten WP, Lieberherr M, Giese G, Wrehlke C, Stamm O, Sekeris CE, Mossmann H \& Wunderlich F 1999 Functional testosterone receptors in plasma membranes of T cells. FASEB Journal 13 123-133.

Bizzarro A, Valentini G, Di Martino G, DaPonte A, De Bellis A \& Iacono G 1987 Influence of testosterone therapy on clinical and immunological features of autoimmune diseases associated with Klinefelter's syndrome. Journal of Clinical Endocrinology and Metabolism 64 32-36.

Blazkovec AA \& Orsini MW 1976 Ontogenetic aspects of sexual dimorphism and the primary immune response to sheep erythrocytes in hamsters from prepuberty through senescence. International Archives of Allergy and Applied Immunology 50 55-67.

Butterworth M, McClellan B \& Allansmith M 1967 Influence of sex in immunoglobulin levels. Nature 214 1224-1225.

Buyon JP, Belmont HM \& Kalunian KC 1995 Postmenopausal hormone therapy and systemic lupus erythematosus. Annals of Internal Medicine 123961.

Catania A, Mangone I, Motta P \& Zanussi C 1989 Administration of gonadotropin-releasing hormone analog as adjunctive therapy in women with systemic lupus erythematosus. Arthritis and Rheumatism 32 1186-1188.

Chen HF, Jeung EB, Stephenson M \& Leung PC 1999 Human peripheral blood mononuclear cells express gonadotropin-releasing hormone $(\mathrm{GnRH}), \mathrm{GnRH}$ receptor, and interleukin-2 receptor gamma-chain messenger ribonucleic acids that are regulated by $\mathrm{GnRH}$ in vitro. Journal of Clinical Endocrinology and Metabolism 84 743-750.

Cheng KW, Cheng CK \& Leung PC 2001 Differential role of PR-A and $-\mathrm{B}$ isoforms in transcription regulation of human $\mathrm{GnRH}$ receptor gene. Molecular Endocrinology 15 2078-2092.

Coddington CC, Brzyski R, Hansen KA, Corley DR, McIntyre-Seltman K \& Jones HW Jr 1992 Short term treatment with leuprolide acetate is a successful adjunct to surgical therapy of leiomyomas of the uterus. Surgical Gynecology and Obstetrics $\mathbf{1 7 5}$ $57-63$.

Currie WD, Steele GL, Yuen BH, Kordon C, Gautron JP \& Leung PC 1993 LHRH- and (hydroxyproline9)LHRH-stimulated hCG secretion from perifused first-trimester placental cells. Recent Progress in Hormone Research 48 505-509.

Deguchi K, Kamada M, Irahara M, Maegawa M, Yamamoto S, Ohmoto Y, Murata K, Yasui T, Yamano S \& Aono T 2001 Postmenopausal changes in production of type 1 and type 2 cytokines and the effects of hormone replacement therapy. Menopause 8 266-273.

Eidinger D \& Garrett TJ 1972 Studies of the regulatory effects of the sex hormones on antibody formation and stem cell differentiation. Journal of Experimental Medicine 136 1098-1116.

Ellis TM, Moser MT, Le PT, Flanigan RC \& Kwon ED 2001 Alterations in peripheral B cells and B cell progenitors following androgen ablation in mice. International Immunology 13 553-558.

Erlandsson MC, Ohlsson C, Gustafsson JA \& Carlsten H 2001 Role of oestrogen receptors alpha and beta in immune organ development and in oestrogen-mediated effects on thymus. Immunology 103 $17-25$.

Eskay RL, Warberg J, Mical RS \& Porter JC 1975 Prostaglandin E2-induced release of LHRH into hypophysial portal blood (1). Endocrinology 97 816-824. 
Fitzpatrick FT, Kendall MD, Wheeler MJ, Adcock IM \& Greenstein BD 1985 Reappearance of thymus of ageing rats after orchidectomy. Journal of Endocrinology 106 R17-R19.

Flores KG, Li J, Sempowski GD, Haynes BF \& Hale LP 1999 Analysis of the human thymic perivascular space during aging. Journal of Clinical Investigation 104 1031-1039.

Folomeev M, Dougados M, Beaune J, Kouyoumdjian JC, Nahoul K, Amor B \& Alekberova Z 1992 Plasma sex hormones and aromatase activity in tissues of patients with systemic lupus erythematosus. Lupus 1 191-195.

Fox HS 1992 Androgen treatment prevents diabetes in nonobese diabetic mice. Journal of Experimental Medicine 175 1409-1412.

French MA \& Hughes P 1983 Systemic lupus erythematosus and Klinefelter's syndrome. Annals of the Rheumatic Diseases 42 471-473.

Funabashi T, Brooks PJ, Weesner GD \& Pfaff DW 1994 Luteinizing hormone-releasing hormone receptor messenger ribonucleic acid expression in the rat pituitary during lactation and the estrous cycle. Journal of Neuroendocrinology 6 261-266.

Garzetti GG, Ciavattini A, Provinciali M, Muzzioli M, Di Stefano G \& Fabris N 1996 Natural cytotoxicity and GnRH agonist administration in advanced endometriosis: positive modulation on natural killer activity. Obstetrics and Gynecology 88 234-240.

Giltay EJ, Fonk JC, von Blomberg BM, Drexhage HA, Schalkwijk C \& Gooren LJ 2000 In vivo effects of sex steroids on lymphocyte responsiveness and immunoglobulin levels in humans. Journal of Clinical Endocrinology and Metabolism 85 1648-1657.

Gould KG, Akinbami MA \& Mann DR 1998 Effect of neonatal treatment with a gonadotropin releasing hormone antagonist on developmental changes in circulating lymphocyte subsets: a longitudinal study in male rhesus monkeys. Developmental and Comparative Immunology 22 457-467.

Grasso G, Massai L, De L V \& Muscettola M 1998 The effect of LHRH and TRH on human interferon-gamma production in vivo and in vitro. Life Sciences 62 2005-2014.

Greenstein BD, Fitzpatrick FT, Adcock IM, Kendall MD \& Wheeler MJ 1986 Reappearance of the thymus in old rats after orchidectomy: inhibition of regeneration by testosterone. Journal of Endocrinology 110 417-422.

Guevara Patino JA, Marino MW, Ivanov VN \& Nikolich-Zugich J 2000 Sex steroids induce apoptosis of CD8+CD4+ double-positive thymocytes via TNF-alpha. European Journal of Immunology $\mathbf{3 0}$ 2586-2592.

Ho HN, Chen HF, Chen SU, Chao KH, Yang YS, Huang SC, Lee TY \& Gill TJ III 1995 Gonadotropin releasing hormone (GnRH) agonist induces down-regulation of the CD3+CD25+ lymphocyte subpopulation in peripheral blood. American Journal of Reproductive Immunology 33 243-252.

Hoffman GE, Le WW, Murphy AZ \& Koski CL 2001 Divergent effects of ovarian steroids on neuronal survival during experimental allergic encephalitis in Lewis rat. Experimental Neurology 171 272-284.

Holmdahl R 1989 Estrogen exaggerates lupus but suppresses T-cell-dependent autoimmune disease. Journal of Autoimmunity 2 651-656.

Hsu CC, Lin YS, Wang ST \& Huang KE 1997 Immunomodulation in women with endometriosis receiving $\mathrm{GnRH}$ agonist. Obstetrics and Gynecology 89 993-998.

Huben RP 1992 Hormone therapy of prostatic bone metastases. Advances in Experimental Medicine and Biology 324 305-316.

Jacobson JD 2000 Gonadotropin-releasing hormone and G proteins: potential roles in autoimmunity. Annals of the New York Academy of Sciences 917 809-818.

Jacobson JD, Nisula BC \& Steinberg AD 1994 Modulation of the expression of murine lupus by gonadotropin-releasing hormone analogs. Endocrinology $1342516-2523$.

Jacobson JD, Crofford LJ, Sun L \& Wilder RL 1998 Cyclical expression of $\mathrm{GnRH}$ and $\mathrm{GnRH}$ receptor mRNA in lymphoid organs. Neuroendocrinology 67 117-125.
Jacobson JD, Ansari MA, Kinealy M \& Muthukrishnan V 1999a Gender-specific exacerbation of murine lupus by gonadotropin-releasing hormone: potential role of $\mathrm{G}$ alpha(q/11). Endocrinology 140 3429-3437.

Jacobson JD, Ansari MA, Mansfield ME, McArthur CP \& Clement LT $1999 b$ Gonadotropin-releasing hormone increases CD4 T-lymphocyte numbers in an animal model of immunodeficiency. Journal of Allergy and Clinical Immunology 104 653-658.

Jamieson BD, Douek DC, Killian S, Hultin LE, Scripture-Adams DD, Giorgi JV, Marelli D, Koup RA \& Zack JA 1999 Generation of functional thymocytes in the human adult. Immunity 10 569-575.

Jansson L, Olsson T \& Holmdahl R 1994 Estrogen induces a potent suppression of experimental autoimmune encephalomyelitis and collagen-induced arthritis in mice. Journal of Neuroimmunology $\mathbf{5 3}$ 203-207.

Kamada M, Irahara M, Maegawa M, Yasui T, Yamano S, Yamada M, Tezuka M, Kasai Y, Deguchi K, Ohmoto Y et al. 2001 B cell subsets in postmenopausal women and the effect of hormone replacement therapy. Maturitas 37 173-179.

Kanda N \& Tamaki K 1999 Estrogen enhances immunoglobulin production by human PBMCs. Journal of Allergy and Clinical Immunology 103 282-288.

Kawashima I, Seiki K, Sakabe K, Ihara S, Akatsuka A \& Katsumata Y 1992 Localization of estrogen receptors and estrogen receptor mRNA in female mouse thymus. Thymus 20 115-121.

Kiess W, Liu LL \& Hall NR 1991 Lymphocyte subset distribution and natural killer cell activity in men with idiopathic hypogonadotropic hypogonadism. Acta Endocrinologica 124 399-404.

Kim S, Liva SM, Dalal MA, Verity MA \& Voskuhl RR 1999 Estriol ameliorates autoimmune demyelinating disease: implications for multiple sclerosis. Neurology 52 1230-1238.

Kincade PW, Medina KL, Payne KJ, Rossi MI, Tudor KS, Yamashita Y \& Kouro T 2000 Early B-lymphocyte precursors and their regulation by sex steroids. Immunological Reviews 175 128-137.

Kipen Y, Strauss BJ \& Morand EF 1998 Body composition in systemic lupus erythematosus. British Journal of Rheumatology 37 514-519.

Kocar IH, Yesilova Z, Ozata M, Turan M, Sengul A \& Ozdemir I 2000 The effect of testosterone replacement treatment on immunological features of patients with Klinefelter's syndrome. Clinical and Experimental Immunology 121 448-452.

Kovacs WJ \& Olsen NJ 1987 Androgen receptors in human thymocytes. Journal of Immunology 139 490-493.

Kreidstein S, Urowitz MB, Gladman DD \& Gough J 1997 Hormone replacement therapy in systemic lupus erythematosus. Journal of Rheumatology 24 2149-2152.

Lahita RG 1986 The influence of sex hormones on the disease systemic lupus erythematosus. Springer Seminars in Immunopathology 9 305-314.

Lahita RG, Bradlow HL, Fishman J \& Kunkel HG 1982 Abnormal estrogen and androgen metabolism in the human with systemic lupus erythematosus. American Journal of Kidney Diseases 2 206-211.

Leposavic G, Karapetrovic B, Obradovic S, Vidiic DB \& Kosec D 1996 Differential effects of gonadectomy on the thymocyte phenotypic profile in male and female rats. Pharmacology, Biochemistry, and Behavior 54 269-276.

Leposavic G, Obradovic S, Kosec D, Pejcic-Karapetrovic B \& Vidic-Dankovic B 2001 In vivo modulation of the distribution of thymocyte subsets by female sex steroid hormones. International Immunopharmacology 1 1-12.

Lichtman MA, Vaughan JH \& Hames CG 1967 The distribution of serum immunoglobulins, anti-gamma-G globulins ('rheumatoid factors') and antinuclear antibodies in White and Negro subjects in Evans County, Georgia. Arthritis and Rheumatism 10 204-215.

Maier CC \& Blalock JE 1994 PCR-based cloning, sequencing, and exon mapping of lymphocyte-derived neuroendocrine peptides. Immunomethods 5 3-7. 
Maier CC, Marchetti B, LeBoeuf RD \& Blalock JE 1992 Thymocytes express a mRNA that is identical to hypothalamic luteinizing hormone-releasing hormone mRNA. Cellular and Molecular Neurobiology 12 447-454.

Mann DR, Ansari AA, Akinbami MA, Wallen K, Gould KG \& McClure HM 1994 Neonatal treatment with luteinizing hormone-releasing hormone analogs alters peripheral lymphocyte subsets and cellular and humorally mediated immune responses in juvenile and adult male monkeys. Journal of Clinical Endocrinology and Metabolism 78 292-298.

Mann DR, Howie S, Paulsen DF, Akinbami MA, Lunn SF \& Fraser HM 1998 Changes in lymphoid tissue after treatment with a gonadotropin releasing hormone antagonist in the neonatal marmoset (Callithrix jacchus). American Journal of Reproductive Immunology 39 256-265.

Marchetti B, Guarcello V, Morale MC, Bartoloni G, Farinella Z, Cordaro S \& Scapagnini U 1989a Luteinizing hormone-releasing hormone-binding sites in the rat thymus: characteristics and biological function. Endocrinology 125 1025-1036.

Marchetti B, Guarcello V, Morale MC, Bartoloni G, Raiti F, Palumbo G Jr, Farinella Z, Cordaro S \& Scapagnini U 1989b Luteinizing hormone-releasing hormone (LHRH) agonist restoration of age-associated decline of thymus weight, thymic LHRH receptors, and thymocyte proliferative capacity. Endocrinology 125 $1037-1045$

Marchetti B, Gallo F, Farinella Z, Tirolo C, Testa N, Caniglia S \& Morale MC 2000 Gender, neuroendocrine-immune interactions and neuron-glial plasticity. Role of luteinizing hormone-releasing hormone (LHRH). Annals of the New York Academy of Sciences 917 678-709.

McArdle CA, Schomerus E, Groner I \& Poch A 1992 Estradiol regulates gonadotropin-releasing hormone receptor number, growth and inositol phosphate production in alpha T3-1 cells. Molecular and Cellular Endocrinology 87 95-103.

Medina KL \& Kincade PW 1994 Pregnancy-related steroids are potential negative regulators of $\mathrm{B}$ lymphopoiesis. PNAS $\mathbf{9 1}$ 5382-5386.

Medina KL, Smithson G \& Kincade PW 1993 Suppression of B lymphopoiesis during normal pregnancy. Journal of Experimental Medicine 178 1507-1515.

Meier CR, Sturkenboom MC, Cohen AS \& Jick H 1998 Postmenopausal estrogen replacement therapy and the risk of developing systemic lupus erythematosus or discoid lupus. Journal of Rheumatology 25 1515-1519.

Metcalfe W \& Boulton-Jones JM 1997 Exacerbation of lupus nephritis in association with leuprorelin injection for uterine leiomyoma. Nephrology, Dialysis, Transplantation 12 1699-1700.

Miyagawa S, Shirai T, Shimamoto I, Ichijo M \& Ueki H 1994 Worsening of systemic lupus erythematosus-associated thrombocytopenia after administration of gonadotropin-releasing hormone analog. Arthritis and Rheumatism 37 1708-1709.

Mok CC, Lau CS, Ho CT, Lee KW, Mok MY \& Wong RW 1998 Safety of hormonal replacement therapy in postmenopausal patients with systemic lupus erythematosus. Scandinavian Journal of Rheumatology 27 342-346.

Morale MC, Batticane N, Bartoloni G, Guarcello V, Farinella Z, Galasso MG \& Marchetti B 1991 Blockade of central and peripheral luteinizing hormone-releasing hormone (LHRH) receptors in neonatal rats with a potent $\mathrm{LHRH}$-antagonist inhibits the morphofunctional development of the thymus and maturation of the cell-mediated and humoral immune responses. Endocrinology 128 1073-1085.

Morale MC, Gallo F, Tirolo C, Testa N, Caniglia S, Marletta N, Spina-Purrello V, Avola R, Caucci F, Tomasi P et al. 2001 Neuroendocrine-immune (NEI) circuitry from neuron-glial interactions to function: focus on gender and HPA-HPG interactions on early programming of the NEI system. Immunology and Cell Biology 79 400-417.
Mosselman S, Polman J \& Dijkema R 1996 ER beta: identification and characterization of a novel human estrogen receptor. FEBS Letters 392 49-53.

Muller D, Chen M, Vikingsson A, Hildeman D \& Pederson K 1995 Oestrogen influences CD4+ T-lymphocyte activity in vivo and in vitro in beta 2-microglobulin-deficient mice. Immunology 86 162-167.

Neely EK, Hintz RL, Parker B, Bachrach LK, Cohen P, Olney R \& Wilson DM 1992 Two-year results of treatment with depot leuprolide acetate for central precocious puberty. Journal of Pediatrics $121634-640$.

Nilsson B, Bergqvist A, Lindblom D, Ljungberg O, Sodergard R \& von Schoultz B 1986 Characterization and localization of specific oestrogen binding in the human thymus. Gynecologic and Obstetric Investigation 21 150-157.

Okuyama R, Abo T, Seki S, Ohteki T, Sugiura K, Kusumi A \& Kumagai K 1992 Estrogen administration activates extrathymic T cell differentiation in the liver. Journal of Experimental Medicine $\mathbf{1 7 5}$ 661-669

Olsen NJ \& Kovacs WJ 1995 Case report: testosterone treatment of systemic lupus erythematosus in a patient with Klinefelter's syndrome. American Journal of the Medical Sciences 310 158-160.

Olsen NJ \& Kovacs WJ 1996 Gonadal steroids and immunity. Endocrine Reviews 17 369-384.

Olsen NJ \& Kovacs WJ 2001 Effects of androgens on T and B lymphocyte development. Immunologic Research 23 281-288.

Olsen NJ, Watson MB, Henderson GS \& Kovacs WJ 1991 Androgen deprivation induces phenotypic and functional changes in the thymus of adult male mice. Endocrinology 129 2471-2476.

Olsen NJ, Viselli SM, Fan J \& Kovacs WJ 1998 Androgens accelerate thymocyte apoptosis. Endocrinology 139 748-752.

Olsen NJ, Olson G, Viselli SM, Gu X \& Kovacs WJ 2001 Androgen receptors in thymic epithelium modulate thymus size and thymocyte development. Endocrinology 142 1278-1283.

Ostensen M 1999 Sex hormones and pregnancy in rheumatoid arthritis and systemic lupus erythematosus. Annals of the New York Academy of Sciences 876 131-143.

Petraglia F, Florio P, Nappi C \& Genazzani AR 1996 Peptide signaling in human placenta and membranes: autocrine, paracrine, and endocrine mechanisms. Endocrine Reviews 17 156-186.

Petri M, Perez-Gutthann S, Spence D \& Hochberg MC 1992 Risk factors for coronary artery disease in patients with systemic lupus erythematosus. American Journal of Medicine 93 513-519.

Phuc LH, Papiernik M, Berrih S \& Duval D 1981 Thymic involution in pregnant mice. I. Characterization of the remaining thymocyte subpopulations. Clinical and Experimental Immunology 44 247-252.

Poulin JF, Viswanathan MN, Harris JM, Komanduri KV, Wieder E, Ringuette N, Jenkins M, McCune JM \& Sekaly RP 1999 Direct evidence for thymic function in adult humans. Journal of Experimental Medicine 190 479-486.

Quinones-Jenab V, Jenab S, Ogawa S, Funabashi T, Weesner GD \& Pfaff DW 1996 Estrogen regulation of gonadotropin-releasing hormone receptor messenger RNA in female rat pituitary tissue. Molecular Brain Research 38 243-250.

Rao LV, Cleveland RP \& Ataya KM 1993 Alterations in thymic and bone marrow lymphocyte subpopulations in $\mathrm{GnRH}$ agonist treated prepubertal female mice. Journal of Reproductive Immunology 25 167-184.

Rao LV, Cleveland RP, Kimmel RJ \& Ataya KM 1995 Hematopoietic stem cell antigen-1 (Sca-1) expression in different lymphoid tissues of female mice treated with GnRH agonist. American Journal of Reproductive Immunology 34 257-266.

Roubinian JR, Papoian R \& Talal N 1977a Androgenic hormones modulate autoantibody responses and improve survival in murine lupus. Journal of Clinical Investigation 59 1066-1070.

Roubinian JR, Papoian R \& Talal N $1977 b$ Effects of neonatal thymectomy and splenectomy on survival and regulation of autoantibody formation in NZB/NZW F1 mice. Journal of Immunology 118 1524-1529. 
Roubinian JR, Talal N, Greenspan JS, Goodman JR \& Siiteri PK 1978 Effect of castration and sex hormone treatment on survival, anti-nucleic acid antibodies, and glomerulonephritis in NZB/NZW F1 mice. Journal of Experimental Medicine 147 1568-1583.

Sanchez-Guerrero J, Liang MH, Karlson EW, Hunter DJ \& Colditz GA 1995 Postmenopausal estrogen therapy and the risk for developing systemic lupus erythematosus. Annals of Internal Medicine 122 430-433.

Schuurs AH \& Verheul HA 1990 Effects of gender and sex steroids on the immune response. Journal of Steroid Biochemistry and Molecular Biology 35 157-172.

Screpanti I, Morrone S, Meco D, Santoni A, Gulino A, Paolini R, Crisanti A, Mathieson BJ \& Frati L 1989 Steroid sensitivity of thymocyte subpopulations during intrathymic differentiation. Effects of 17 beta-estradiol and dexamethasone on subsets expressing $\mathrm{T}$ cell antigen receptor or IL-2 receptor. Journal of Immunology 142 $3378-3383$

Sempowski GD, Hale LP, Sundy JS, Massey JM, Koup RA, Douek DC, Patel DD \& Haynes BF 2000 Leukemia inhibitory factor, oncostatin M, IL-6, and stem cell factor mRNA expression in human thymus increases with age and is associated with thymic atrophy. Journal of Immunology 164 2180-2187.

Siiteri PK, Jones LA, Roubinian J \& Talal N 1980 Sex steroids and the immune system - I. Sex difference in autoimmune disease in NZB/NZW hybrid mice. Journal of Steroid Biochemistry and Molecular Biology 12 425-432.

Silveira LF, Stewart PM, Thomas M, Clark DA, Bouloux PM \& MacColl GS 2002 Novel homozygous splice acceptor site GnRH receptor (GnRHR) mutation: human GnRHR 'knockout'. Journal of Clinical Endocrinology and Metabolism 87 2973-2977.

Smithson G, Medina K, Ponting I \& Kincade PW 1995 Estrogen suppresses stromal cell-dependent lymphopoiesis in culture. Journal of Immunology 155 3409-3417.

Smithson G, Couse JF, Lubahn DB, Korach KS \& Kincade PW 1998 The role of estrogen receptors and androgen receptors in sex steroid regulation of B lymphopoiesis. Journal of Immunology 161 27-34.

Standaert FE, Chew BP, De Avila D \& Reeves JJ 1992 Presence of luteinizing hormone-releasing hormone binding sites in cultured porcine lymphocytes. Biology of Reproduction 46 997-1000.

Staples JE, Gasiewitcz TA, Fiore NC, Lubahn DB, Korach KS \& Silverstone AE 1999 Estrogen receptor $\alpha$ is necessary in thymic development and estradiol-induced thymic alterations. Journal of Immunology 163 4168-4174.

Steinmann GG, Klaus B \& Muller-Hermelink HK 1985 The involution of the ageing human thymic epithelium is independent of puberty. A morphometric study. Scandinavian Journal of Immunology 22 563-575.

Stern R, Fishman J, Brusman H \& Kunkel HG 1977 Systemic lupus erythematosus associated with Klinefelter's syndrome. Arthritis and Rheumatism 20 18-22.

Suenaga R, Evans MJ, Mitamura K, Rider V \& Abdou NI 1998 Peripheral blood $\mathrm{T}$ cells and monocytes and $\mathrm{B}$ cell lines derived from patients with lupus express estrogen receptor transcripts similar to those of normal cells. Journal of Rheumatology 25 1305-1312.

Tremblay GB, Tremblay A, Copeland NG, Gilbert DJ, Jenkins NA, Labrie F \& Giguere V 1997 Cloning, chromosomal localization, and functional analysis of the murine estrogen receptor beta. Molecular Endocrinology 11 353-365.

Verthelyi D \& Ahmed SA 1994 17-beta-estradiol, but not 5-alphadihydrotestosterone, augments antibodies to double-stranded deoxyribonucleic acid in nonautoimmune C57BL/6J mice. Endocrinology 135 2615-2622.

Verthelyi D \& Ansar AS 1997 Characterization of estrogen-induced autoantibodies to cardiolipin in non-autoimmune mice. Journal of Autoimmunity 10 115-125.

Viselli SM, Olsen NJ, Shults K, Steizer Gi \& Kovacs WJ 1995 Immunochemical and flow cytometric analysis of androgen receptor expression in thymocytes. Molecular and Cellular Endocrinology 109 $19-26$.

Walker SE \& Jacobson JD 2000 Roles of prolactin and gonadotropinreleasing hormone in rheumatic diseases. Rheumatic Diseases Clinics of North America 26 713-736.

Walker SE, McMurray RW, Houri JM, Allen SH, Keisler D, Sharp GC \& Schlechte JA 1998 Effects of prolactin in stimulating disease activity in systemic lupus erythematosus. Annals of the New York Academy of Sciences 840 762-772.

Waller KG \& Shaw RW 1993 Gonadotropin-releasing hormone analogues for the treatment of endometriosis: long-term follow-up. Fertility and Sterility 59 511-515.

Weesner GD, Becker BA \& Matteri RL 1997 Expression of luteinizing hormone-releasing hormone and its receptor in porcine immune tissues. Life Sciences 61 1643-1649.

Weinstein Y, Ran S \& Segal S 1984 Sex-associated differences in the regulation of immune responses controlled by the $\mathrm{MHC}$ of the mouse. Journal of Immunology 132 656-661.

Whitacre CC 2001 Sex differences in autoimmune disease. Nature Immunology 2 777-780.

Wilson CA, Mrose SA \& Thomas DW 1995a Enhanced production of B lymphocytes after castration. Blood 85 1535-1539.

Wilson TM, Yu-Lee LY \& Kelley MR 19956 Coordinate gene expression of luteinizing hormone-releasing hormone (LHRH) and the LHRH-receptor after prolactin stimulation in the rat $\mathrm{Nb} 2$ T-cell line: implications for a role in immunomodulation and cell cycle gene expression. Molecular Endocrinology 9 44-53.

Wolfahrt S, Kleine B \& Rossmanith WG 1998 Detection of gonadotrophin releasing hormone and its receptor mRNA in human placental trophoblasts using in-situ reverse transcription-polymerase chain reaction. Molecular Human Reproduction 4 999-1006.

Yellayi S, Teuscher C, Woods JA, Welsh TH, Tung KS, Nakai M, Rosenfeld CS, Lubahn DB \& Cooke PS 2000 Normal development of thymus in male and female mice requires estrogen/estrogen receptor-alpha signaling pathway. Endocrine 12 207-213.

Yesilova Z, Ozata M, Kocar IH, Turan M, Pekel A, Sengul A \& Ozdemir IC 2000 The effects of gonadotropin treatment on the immunological features of male patients with idiopathic hypogonadotropic hypogonadism. Journal of Clinical Endocrinology and Metabolism 85 66-70.

Zakharova LA, Malyukova IV, Adamskaya EI, Kuznetsova TA \& Shishkina IV 2000 Luteinizing hormone-releasing hormone in thymus and hypothalamus of rat fetuses: suppressing effect of antagonist and of antibodies on concanavalin A-induced proliferation of thymocytes. Biochemistry (Moscow) 65 1135-1139.

Received 10 September 2002

Accepted 11 November 2002 